\title{
Giving Permission to Play in Higher Education
}

\section{Walsh, Andrew}

Teaching Fellow Computing and Library Services, University of Huddersfield, United Kingdom

\begin{abstract}
Playing in public, including within education, is a political act, one that is loaded with potential disapproval by others, and hence becomes difficult for potential players to do. Even so, play has many potential benefits within Higher Education. This paper describes some of the benefits to play and describes the social difficulty of playing through the lens of Goffman's frames. It goes onto describe some ways in which playful learning can be introduced to increase the social acceptability and impact of play within Higher Education. These are steps towards constructing a playful frame in which students and staff can view Higher Education. No absolute guidelines could be produced, as both play and acceptability of it are socially constructed and are so completely contextual, but an overall approach is suggest to increase the understanding, acceptability, and effectiveness of play.
\end{abstract}

Keywords: Play; game based learning; Goffman. 


\section{Introduction}

Playing in public, or in particular, being seen to play in public, is a political act for adults (Koh, 2014; De Koven, 2014, p. 160). Outside socially mandated acceptable modes and arenas of play (such as playing for a sports team, belonging to an amateur dramatics society, etc.), play tends to be seen as socially unacceptable for adults, reducing the amount of play they undertake, particularly free or imaginative play (Van Leet \& Feeney, 2015).

Nevertheless, play has clear benefits in Higher Education for lecturers, researchers, and students. The meaning of play is outlined for the purposes of this paper, along with some key benefits of play. Using the idea of frames of social interaction (Goffman, 1986) as a lens through which to study play in adult education, we will suggest ways in which a playful frame may be encouraged within Higher Education to give students permission to play within their time at University.

\section{The Nature and Benefits of Play in HE}

Play is both a personally and socially constructed idea. Whether something is play can depend on the person and people involved, and the time and context in which an activity is taking place. As Glen and Knapp (1987, p. 52) say, '...any sequence to be considered playful as long as the interactants perceive it to be such and signal their understanding accordingly', so as long as participants decide to frame an activity as play to each other, then it can validly be seen as play. Accordingly, definitions of play vary and are often best described by lists of attributes that might describe the activity of play.

'Summing up the formal characteristic of play, we might call it a free activity standing quite consciously outside 'ordinary' life as being 'not serious' but at the same time absorbing the player intensely and utterly. It is an activity connected with no material interest, and no profit can be gained by it. It proceeds within its own proper boundaries of time and space according to fixed rules and in an orderly manner. It promotes the formation of social groupings that tend to surround themselves with secrecy and to stress the difference from the common world by disguise or other means.' (Huizinga, 1955)

So according to Huizinga, who strongly influenced the field of play research, play is an activity that somehow steps outside of normal life (while still, of course, allowing normal life to impinge if necessary), where different rules can apply than in the "real" world. It is "pointless", in that we do not play to gain any benefit outside the act of play itself, even though benefits may occur. It tends to be a social activity, with players often choosing to signal a separation of the playing group from the outside world. Huizinga also described some different arena in which people play, and one of his terms, the "magic circle" is often 
used as a short-cut to describe that idea of stepping out of normal life into a different world constructed through play.

The nature of being able to improvise, to change the rules to suit the players, can serve as the distinction between two different types of play. Caillois called these Paidia and Ludus (Caillois, R. and Barash, M. , 2001), which Paidia being a free, imaginative play form, and Ludus being highly structured and inflexibly rule based. So a child's "make believe" game would be primarily Paidia, and a crossword puzzle primarily Ludus. Often when we think of "games", these are highly Ludic in nature, with "play" as highly Paidic. In reality, all games and play activities lie on this spectrum, and even highly structured games can be a vehicle for delivering play (or Paidic play forms), if we allow them to do so.

Play has multiple benefits in Higher Education (Walsh \& Clementson, 2017), but we will focus on just four in this paper. Improved group and team working skills, deeper and more critical interaction with subject material, encouragement of increased creativity, and because play is often fun.

Improving group and team working skills is often a key reason for bringing play into organisations, which may be echoed in the Higher Education environment. Play tends to be a social activity, and depends on negotiating implicit and explicit rules amongst the players. It can be seen as an opportunity to practice and improve these team working abilities valued in many work roles that graduates will find themselves, and playful activities have been found to have value themselves, for these reasons, in the workplace (Statler et al, 2009; Owler et al, 2010). This aspect of play also feeds into student retention, increasing a sense of belonging to a group that has repeatedly been seen as valuable in retaining students (Gerrard \& Billington, 2014; Morrow \& Ackermann, 2012), though play and playfulness are not normally studied as a factor in retention.

For education in particular, the stepping into the "magic circle" of play, has great benefit for deeper and more critical interaction with subject material. Play allows learners to make mistakes, often repeatedly, within being penalised. This is relatively unusual in education, which can be dominated by learning "to the test", with value placed on knowledge only as far as it can be used to pass onto the next level of study. Play can allow the sort of experimentation with skills and knowledge that encourages the sort of practicing and playing in liminal spaces that leads to transformational learning through the deeper understanding of threshold concepts (Meyer et al, 2010) within a subject area. This is reinforced by the ability to see the world through the lens of ourselves as players, which may be different to our normal personas. We have a "diminished consciousness of self" (Brown \& Vaughan, 2010) when playing, which lets us inhabit different characters to our own, allowing more critical perspectives to be designed into learning experiences. 
Creativity, an attribute greatly valued by $21^{\text {st }}$ Century employers, is something that is often synonymous with play in education. Again, the "magic circle", allows us to fail without penalty, with the Paidic aspects of play and games naturally encouraging creative practice. The entire business of universities can be seen as creating new knowledge, and so creativity should be seen as a keystone of a successful Higher Education institution. Playing has repeatedly been seen as a promotor of creativity in education and the workplace (Chang et al, 2013; West et al, 2016; West et al, 2013) and encouraging playfulness (through play), is also seen as strongly related to creativity (Lieberman, 1977).

Fun is often seen as the major reason for introducing play in the workplace, and in adult education, but is often ignored by the academic literature, though it is a major driver for introducing play elsewhere in play writings (e.g. De Koven, 2014). Fun can be seen as frivolous, a distraction from the serious work of education, even though there is evidence that fun, and other positive emotions, improve memory retention (Judde \& Rickard, 2010) and learning (Hromek \& Roffey, 2009).

\section{Goffman's frames}

This paper will use Goffman's (1986) idea of sociological frames as a way of looking at how we might enable play in Higher Education, and so achieve some of the benefits outlined above. Goffman (1971, p. 28) describes how individuals tend to play a part in any situation, asking them to 'believe that the character they see, actually possesses the attributes he appears to possess'. He talks a great deal about play, including listing nine things that must be sustained to "transform serious, real action into something playful" (Goffman, 1986, p. 41). Most importantly, he describes how keys, or keying (conventions by which an activity is perceived by participants) allow a group to decide whether or not a certain activity is play. The "frame" in which we see an activity is controlled by the internal and external prompts that affect how we react to it.

For instance, if we walk into a lecture theatre with fixed tiered seating, and see someone at the front with slides ready, we are likely to see it through a frame akin to a Victorian, didactic mode of teaching. We expect to sit still and silent for a set amount of time and be fed information from the expert at the front. Creativity and conversation will seem alien to the frame, clashing with the behavior that the group would expect from each other in that situation. To act differently to the norms of expected behavior in any situation causes "embarrassment" (Goffman, 1967) to both the non-comformer and those around them.

Members of any group naturally signal to each other when they move into a play situation (Glenn et al, 1987), and a combination of this informal signaling and contextual signaling is required to enable a playful frame for learning. 


\section{Developing a playful frame for HE, or "giving permission to play"}

As already stated, public play is a political act. Playing in an educational setting can be seen as acting against the normative frame of that social setting. So how can we make it the norm? How can it a playful frame be accepted in Higher Education settings?

Deterling (2017) uses Goffman's frames to suggest that people need 'alibis' to play, to give excuses for behaving differently to how a normative frame might suggest in a particular situation, as well as keyings (see above) that can help move the frame appropriately. He suggests that if we remove the potential for disapproving observers (Audience management); interrupt the ability for players and observers to watch each other (Awareness management); and encouraging participants to distance themselves from the play through parody or mocking the play, even while taking part (Role distancing).

I outline here ways in which we may shift the frame of normal behaviour within a Higher Education setting to one that encourages and enables play. No one way will shift that frame completely, but as each is introduced they may build together an expectation that one "plays" within a course or setting, and it is instead "embarrassing" to not play.

\subsection{Induction or Orientation tasks}

Ideally from the start of a learner's time at university, or at least the start of a module, giving cues that play is "normal" and expected will help to enable play within learning throughout a course. The initial days and weeks in a new setting is where the new "frame" of the social expectations are set out, and prior expectations are reinforced or destroyed. Playful and creative activities such as challenge cards, team building games, and group play help to socially construct the idea that Higher Education is a place to play and experiment with ideas, rather than to sit back and receive "facts" from an expert.

\subsection{Environmental invitations to play}

Lecture theatres immediately signal passive, didactic learning to most of us. But we can build into the environment invitations and expectations of play. In any teaching room, we can use objects on tables such as Lego or modelling clay, pens and paper (to encourage thinking with your hands), and bubbles or fidget toys (as distractions as concentration aid). In classrooms without fixed seating, we can move tables into different configurations (or remove them entirely), encouraging activity, groupwork, and active modes of participation. We can even move outside the normal classroom, using Psychogeographic ideas to prompt new thoughts and ideas in reaction to the environment. Walls should be a place to positively reinforce playful activity, rather than a depository of negative instructions ("Do not..." signage). In short, the expectations students may have around classroom behaviour 
can be altered by changing the classroom environment, and building a new behavioural expectation or frame.

\subsection{Structural invitations to play}

The formal structures of Higher Education are often inimical to play. Not only in how much of it is described ("lecturers" and "lectures", for example), but in set learning objectives for modules and courses, and in related assessment tools to test those outcomes. We can, however, soften the impact on those structures on the social and behavioural expectations of students and so enable an environment that welcomes and encourages play.

It is important to have detailed learning objectives at the start of courses to inform planning and content, but to encourage play, these should not be allowed to prevent serendipitous and emergent learning happening. It is normally seen as best practice to display learning objectives to students in each teaching session, particularly at the start of a class. This locks students into a set of expectations that makes play less acceptable. Only make learning objectives explicit at the start of modules or courses, along with any assignment or assessment briefs in order to enable play. Assessment itself should be as flexible as possible, introduce creative exercises that promote critical thinking about topics, rather than examinations that may promote a rigidity of learning.

\subsection{Pedagogical invitations to play}

Of course, one of the most explicit invitations to play is through designing playful learning experiences. Learning games can be used to allow self-discovery of facts and processes, simulations used to practice skills, and creative exercises to apply and knowledge all encourage a playful approach to the classroom. This could also sit well with the "flipped learning" approach, where students may engage with factual material between timetabled sessions, then carry out more interactive, playful activities within the classroom itself.

\subsection{Allowing people not to play}

It is important to recognize that people can choose not to "play", while still carrying out activities that are inherently designed to enable play. They can still benefit from these activities and approach, just not to as great an extent as someone who embraces play. Once play becomes compulsory, it is no longer play, so the focus must be on encouraging and enabling play, not forcing it.

\section{Conclusion}

Although play can be a valuable approach to learning and Higher Education, it often fails to sit comfortably within that setting. Using Goffman's idea of frames we can see that the 
standard learner expectations of how to act in a Higher Education setting is socially constructed and based on a mixture of prior social experiences and "keyings" from their social environment. We can use the ideas of keys, or social prompts, to change the frame in which learners view their expected behavior.

Approaches that influence how learners view that environment from the start, as well as throughout, a course can introduce play in a way that would be difficult or impossible as "one off" or occasional activities, as we need to build a playful frame for Higher Education for play to be seen as acceptable to learners. Playful cues, or keys, can usefully be introduced in induction or orientation activities, within the physical teaching environment, through structural changes, and through pedagogical invitations to play. These various and mutually reinforcing invitations to play can be used to build this frame, which work together to shift the frame and make play socially acceptable.

\section{References}

Brown, S. L., \& Vaughan, C. C. (2010). Play: how it shapes the brain, opens the imagination, and invigorates the soul. New York: Avery

Chang, C., Hsu, C., \& Chen, I. (2013). The relationship between the playfulness climate in the classroom and student creativity. Quality \& Quantity, 47(3), 1493-1510

Caillois, R. and Barash, M. (2001) Man, play, and games. Urbana: University of Illinois Press.

De Koven, B (2014). A playful path. Halifax, Canada: ETC Press.

Deterling, S. (2017). Alibis for adult play: A Goffmanian account of escaping embarrassment in adult play. Games and Culture, Online first, pp. 1-20. https://doi.org/10.1177/1555412017721086

Gerrard, S., \& Billington, J. (2014). The perceived benefits of belonging to an extracurricular group within a pre-registration nursing course. Nurse Education in Practice, 14(3), pp. 253-258. http://dx.doi.org/10.1016/j.nepr.2013.11.002

Glenn, P. Knapp, M. (1987). The interactive framing of play in adult conversations. Communication Quarterly, 35 (1), pp. 48-66.

Goffman, E. (1967). Interaction ritual; essays in face-to-face behavior. United States: Doubleday.

Goffman, E. (1971). The presentation of self in everyday life. London: Pelican Books.

Goffman, E. (1986). Frame analysis: An essay on the organization of experience (Northeastern University Press ed.). Boston: Northeastern University Press. 
Hromek, R., \& Roffey, S. (2009). Promoting social and emotional learning with games: "it's fun and we learn things". Simulation \& Gaming, 40(5), pp. 626-644. http://dx.doi.org/10.1177/1046878109333793

Huizinga, J. (1955). Homo Ludens: A study of the play element in culture. Boston: Beacon Press.

Judde, S., \& Rickard, N. (2010). The effect of post-learning presentation of music on longterm word-list retention. Neurobiology of Learning and Memory, 94(1), pp. 13-20. http://dx.doi.org/10.1016/j.nlm.2010.03.002

Koh, A (2014). The political power of play. Hybrid Pedagogy. Retrieved from: http://www.digitalpedagogylab.com/hybridped/political-power-of-play/

Lieberman, J. (1977). Playfulness: Its relationship to imagination and creativity. New York: Academic Press, Inc.

Meyer, J., Land, R., \& Baillie, C. (2010). Threshold concepts and transformational learning. Rotterdam: Sense Publishers.

Morrow, J. A., \& Ackermann, M. E. (2012). Intention to persist and retention of first-year students: The importance of motivation and sense of belonging. College Student Journal, 46(3), 483-491.

Owler, K., Morrison, R., \& Plester, B. (2010). Does fun work? The complexity of promoting fun at work. Journal of Management \& Organization, 16(3), pp. 338-352. http://dx.doi.org/10.5172/jmo.16.3.338

Statler, M., Roos, J., \& Victor, B. (2009). Ain't misbehavin': Taking play seriously in organizations. Journal of Change Management, 9(1), pp. 87-107. http://dx.doi.org/10.1080/14697010902727252

Van Vleet, M. \& Feeney, B. (2015). Play behavior and Playfulness in Adulthood. Social and Personality Psychology Compass. 9(11), pp. 630-643. http://dx.doi.org/10.1111/spc3.12205

Walsh, Andrew and Clementson, Jonny (2017) Reasons to play in Higher Education. In: The Power of Play - Voices from the Play Community. CounterPlay, Aarhus, Denmark, pp. 181-187.

West, S. E., Hoff, E., Carlsson, I., Department of Psychology, Lunds universitet, Lund University, \& Institutionen för psykologi. (2016). Play and productivity: Enhancing the creative climate at workplace meetings with play cues. American Journal of Play, 9(1), pp. 71-85.

West, S., Hoff, E., \& Carlsson, I. (2013). Playing at work: Professionals' conceptions of the functions of play on organizational creativity. The International Journal of Creativity and Problem Solving, 23(2), pp. 5-23. 